\title{
THE DESCRIPTIVE STUDY ON THE SECOND YEAR STUDENTS' INTEREST AND MOTIVATION TOWARD PEER ASSISTED LEARNING PROGRAM (PALP) OF ENGLISH EDUCATION DEPARTMENT AHMAD DAHLAN UNIVERSITY IN ACADEMIC YEAR 2016/2017
}

\author{
Novi Sri Rahmi ${ }^{1}$, Arilia Triyoga ${ }^{2}$ \\ ${ }^{1}$ Universitas Ahmad Dahlan, Indonesia \\ ${ }^{1}$ novisrirahmi@gmail.com \\ ${ }^{2}$ Universitas Ahmad Dahlan, Indonesia \\ 2arilia@pbi.uad.ac.id
}

\begin{abstract}
The aims of this research are to describe the students' interest toward PALP, the students' motivation toward PALP, and to describe the social factors affects to students' interest and motivation.

The type of the research is descriptive research. The research subject was the second semester of PBI students in Ahmad Dahlan University in the academic year 2016/ 2017. There were 10 groups of PALP as the sample. The researcher used questionnaire, observation sheet and interview guide to gather the data. In analyzing the data the researcher used quantitative method.

Based on the research, it is found that; first the students' interest toward PALP is in high category based on impression (75\% were agree), confidence ( $82 \%$ were agree in a group of PALP, $85 \%$ were agree in the class), learning atmosphere (84\% were agree), excitement ( $81 \%$ were agree), new knowledge (73\% were agree) and language skill (78\% were agree). Secondly, the students' motivation toward PALP is in high category based on mentees' individual competency in PALP based on how often they are expressing opinion (79\% were agree), responding the question (80\% were agree), and asking question (61\% were agree). And the third, there were four social factors affecting students' interest and motivation. The social factor were positive learning atmosphere ( $84 \%$ were agree), the second was friend ( $80 \%$ were agree). The third was mentor ( $72 \%$ were agree). The last was the place (55\% were agree). The job, gender and distance factor did not affect students' interest and motivation toward PALP.
\end{abstract}

Keywords: interest, motivation, peer learning

\section{INTRODUCTION}

Interest and motivation are two important things in the learning process. Every student should have interest and motivation in able to have a good learning result, especially college students who learn more complicated things. A student who does not have interest and motivation will find difficulties in learning. As a result, they will have low-Grade Point Average (GPA) and it affects their career in the future. Many types of research had conducted to find the correlation between GPA and job career. According to (Koeppel, 2006) in Nicely (2007: 1), "A 2007 survey conducted by the National Association of Colleges and Employers found that over $66 \%$ of companies screen applicants in some manner using GPA". It shows that GPA is a crucial thing in student's life. A good campus will find many ways in order to help students solve their difficulty in learning and order to reach each major goal.

In 2015, Head of English Education Department initiated a program called PALP (Peer Assisted Learning Program). PALP is a program focusing in peer tutoring. PALP focuses on the different skill each semester. PALP is a peer learning 
program; it involves the students in English Education Department. As Boud (2002) states that peers are defined as people who have the same social background who do not have a particular part as a professional teacher.The goal of PALP is providing place and opportunity where students can improve their English skill, share their feeling, problem, experience and also knowledge. During the implementation of PALP in English Education Department, it has some obstacles. There are some students who often don't attend PALP's meeting, come late at PALP's meeting, and passive at the learning process in PALP.

This study aims to describe the students' interest and motivation toward PALP and also the social factors affecting students' interest and motivation toward PALP. Several researches were done related to the study. International Postgraduate Students and Peer Learning had been discussed by Evans Hala in 2015. Assessing the Effects of Interactive Blogging on Student Attitudes towards Peer Interaction, Learning Motivation, and Academic Achievements by Yang, C., \& Chang, Y. S. in 2012. The difference of this study from previous studies is that the writer is going to discuss the students' interest and motivation toward PALP and also the social factors affecting students' interest and motivation toward PALP.

\section{LITERATURE REVIEW}

2.1 Interest

Interest is one of the factors that motive someone to learn. Seifert (2009: 116) states that interest is characterized as a desire which comes from inside of a human. Interest located on the inside of a human. Another definition comes from John Dewey (1913: 17) in Harackiewicz (2009) stated that interest is being connected, absorbed, or fascinated with an action, thing, or theme. Reynolds (2003: 113) states that interest is defined as personal preference toward something that person has for a long time and becomes identity of the person. Based on the definition, interest can be defined as pleasant feeling toward something and make individual to take a part of it.

According to Thorndike (1932), learning is strengthened when it is accompanied by a pleasant or satisfying feeling and that it is weakened when it is associated with an unpleasant experience. When students' interest and their emotional are considered and they have pleasant feeling toward the material they will more likely to take the risk and focus more in the learning process. The student with emotional balance has motivation and usually follows the course successfully. A teacher should work on gaining the heart of the students first than their minds. Since the more excitement a lesson creates, the more likely student will remember it.

The interest toward PALP is students' pleasant feeling toward PALP which is seen by the attention and attitude toward PALP. Interest toward PALP includes their impression and what they feel toward PALP.

The function of student's interest toward PALP is the student will give more attention and show pleasant feeling through their attitude toward PALP in purpose to make a change in their ability and produce a good learning result in PALP.

2.2 Types of Interest

Interest has two forms such as situational interest and personal interest.

a. Situational interest

According to Seifert (2009:119), situational interest "are ones that are triggered temporarily by features of the immediate situation. Unusual sights, sounds, or words can stimulate situational interest". An interest can change depends on 
the situation. Another explanation comes from Schiefele (1991: 302),"situational interest is an emotional state brought about by situational stimuli.

b. Individual interest

According to Seifert (2009: 119),"Personal interests are relatively permanent preferences of the student, and are usually expressed in a variety of situations". The student has various interests over something. The interest usually comes within from the student itself. Schiefele (1991) stated that individual interest is regarded as human selection for specific things such as topic, subject, and activities.

\subsection{Motivation}

In order to do something well, people need motivation. According to Graham (1996: 63), "Motivation is the study of why people think and behave as they do". Another definition comes from Ball (2012), "Motivation, in its broadest sense, can be defined as forces acting either on or within a person to initiate behavior". Lai (2011) states that motivation is a cause which makes people desire to do something. Based on the explanation above, motivation can be defined as factors which move or activate individual to do something to achieve desired goals.

Motivation means having a reason for doing something. Lai (2011) states that motivation is a cause which makes people desire to do something. For example, the reasons why students study or learn in school.It concerns the reasons or goals that underlie their involvement in academic activities. The student who knows what their exact reason to study will reach their goals in the learning process. Their reason to study may differ.

Motivation is one of the forces that lead to performance. The study done by Amrai, K., Motlagh, S. E., Zalani, H. A., \& Parhon, H. (2011) showed that there is high correlation between motivation and academic achievement. It increases the initiation and persistence of activities in the classroom. It can be seen in students' action in learning process. Activities like express opinion, respond the question, and asking the question involve the motivation.

The motivation toward PALP is factors which move or activate students' to do something to achieve desired goals toward PALP which is seen by the students' action in PALPs' meeting.

The function of student's motivation toward PALP is the student will do well in PALP since they have motivation that can be seen in their action in learning process in PALP in purpose to produce a good learning result in PALP.

\subsection{Types of Motivation}

According to Ryan (2000), there are two types of motivation, they are:

a. Intrinsic motivation

According to Ryan (2000: 55), "Intrinsic motivation is defined as the doing of an activity for its inherent satisfactions rather than for some separable consequence". He continues that the motivation coming from the inside of people. For example, we have situations in which the source of motivation lies inside the task. It doesn't need any external source of motivation. Activities such as reading an interesting novel, writing poem or story are related to intrinsic motivation. Interest is a part of the intrinsic motivation.

b. Extrinsic Motivation

Extrinsic motivation is a construct that pertains whenever an activity is done in order to attain some separable outcome (Ryan, 2000: 60). Extrinsic motivation comes from the external part of a person. Undertaking a given task may be 
motivated by a promise of a prize or some other kind of gain which is external to the task.

\subsection{Social Factors Affecting Interest and Motivation}

There are some factors affecting interest and motivation. They are individual and social factors. The individual factor is the factor that comes from within, such as intelligent, talent, maturity, and personality. The social factor is a factor which is caused by surrounding, such as environment, social and economic background and family background. According to Crow (1973:22) in Jani (2012) explain that:

a. The factor of inner urges

A stimulus that coming from the environment and suitable with the desire or need of someone is easier create interest. For example, the tendency towards learning, in this case, a person has a desire to know science.

b. The factor of social motive

Human's interest to object or something. It is influenced by factors inside of the human and also the social motives, for example, someone interested in reaching high achievement to get high social status as well. The social factors can be a friend, parents or the society.

c. Emotional factors

This kind of factor related to emotional feeling toward individual's experience. If the individual through success in a specific object, it will raise their interest in contrast if individual through failure, they will reduce the interest.

According to Ormrod (2006: 424) in Hikmat (2012) states that there are three factors affecting motivation:

1) Ethnic differences

Learners motivation can be affected by ethnic differences. It influences mind, emotion, anxiety and behavior in learning. Students who come from minority ethnic group have a high motivation.

2) Gender differences

Gender influences in motivation. A woman tends to do well in school than man. Woman also works harder than man in school.

3) Socioeconomic difference

Students who coming from low socioeconomic background usually have high motivation because they want to make their life better.

In conclusion, there are some factors influence interest and motivation of the students, they are the environment, family background, gender background, and socioeconomic background.

2.6 Peer learning

Peer learning can be defined as the acquisition of knowledge and skill through active helping and supporting among status equals or matched companions (Topping, 2005: 631). The students who are in the status equal or matched companions refers to students who have the same interest and position in order the students feel comfortable to share their knowledge, experiences and also their problems. As Boud (2002) stated that peers are defined as people who have the same social background who do not have a particular part as a professional teacher. Based on the explanation above, peer learning is a sharing process of knowledge, ideas, and experience among students who has similar situation and concern.

The variety reason of why people must consider implementing peer learning is related to the benefit or advantages the peer learning offers. According to Boud (1999: 4), they are: 
a. giving the students train in designing and understanding in working with each other and also giving them an important role in the learning process,

b. allowing the students in expressing their ideas and opinion independently since there is no professional teacher in the group,

c. increasing the students skill in communication since the interaction among the students is a vital thing in peer learning in order to realize their strength and weakness in the learning process, and

d. preparing the students to become the part of society who have the responsibility to each other since in peer learning they have an obligation to planning and conducting their own learning and assisting each other.

\section{METHODS}

\subsection{Types of Research}

This study belongs to quantitative research because this study use numerical data and statistic. The writer will use descriptive researches since the writer will describe the students' interest and motivation toward PALP and the social factors affecting students' interest and motivation toward PALP.

\subsection{Research Subject, Object and Data}

The researcher chooses the second semester of PBI students in Ahmad Dahlan University in the academic year 2016/ 2017 as the source of collecting the data. In this research, the population is all of the second year students of English education department at Ahmad Dahlan University in the academic year of 2016/2017 that split into 22 groups. The amount of the second year is approximately more than 200.

In determining the number of samples, the researcher uses a sample size 10 out of 22 populations.

\subsection{Method and Technique for Collecting Data}

The researcher use survey, interview, and observation as methods to collect the data. The researcher used questionnaire, observation sheet and interview guide as instruments to gather the data.

\subsection{Method and Technique for Analyzing Data}

To describe the students' interest and motivation and social factors affecting interest and motivation, the researcher uses descriptive quantitative analysis. When the data are completed, the data will be analyzed through the following steps: first, the data in the questionnaire will be scored. Score 1 for strongly disagree, 2 for disagree, 3 for agree, and 4 for strongly agree statement. After that, the data will be written in excel file into few sheets. The first sheet is about written statement about interest and motivation by scoring their questionnaires. Then, score of each statement which contained the number of the respondent. And make the data into percentage form.

\section{FINDINGS AND DISCUSSION}

\subsection{Students' Interest toward PALP}

The researcher used questionnaire, observation sheet and also interview guide to answer this obective. The interest was indicated by pleasant feeling toward the program. The questionnaire was modified of likert scale, strongly agree (4), agree (3), disagree (2), and strongly Disagree (1). Questionnaire consisted 7 statements related to interest. They were number 1,2,3,4,5,6,7. 


\begin{tabular}{lll}
\hline \multicolumn{2}{c}{ Aspect } & Agree Percentage \\
\cline { 2 - 3 } 1. & \multicolumn{2}{c}{ Student interest toward PALP } \\
\cline { 2 - 3 } & a. $\quad$ Impression & $75 \%$ \\
\hline b. $\quad$ Confidence & $82 \%$ \\
\hline c. $\quad$ Learning atmosphere & $84 \%$ \\
\hline d. $\quad$ Excitement & $81 \%$ \\
\hline e. $\quad$ New knowledge & $73 \%$ \\
\hline f. $\quad$ Language skill & $78 \%$ \\
\hline
\end{tabular}

Students' Interest toward PALP of Second-Year Students of English Education of Ahmad Dahlan University in the Academic Year 2016/2017 is in high category based on impression (75\% were agree), confidence ( $82 \%$ were agree in a group of PALP, $85 \%$ were agree in the class), learning atmosphere (84\% were agree), excitement ( $81 \%$ were agree), new knowledge (73\% were agree) and language skill (78\% were agree)

\subsection{Students' Motivation toward PALP}

The researcher used questionnaire, observation sheet and interview guideline to answer this objective. There were 7 statements representing motivation in the questionnaire. They were number $8,9,10,11,12,13$, and 14. Motivation is divided by reason of study and students' action toward the program.

\begin{tabular}{cll}
\hline \multicolumn{1}{c}{ Aspect } & Agree Percentage \\
\hline 2. & & \\
\hline a. & Student motivation toward PALP & \\
\hline & Study reason & $88 \%$ \\
\hline 1). & Good mark & $75 \%$ \\
\hline 3). & Increasing language skill & $73 \%$ \\
\hline 4) & Obligation & $72 \%$ \\
\hline b. & Gaining new knowledge \\
\hline & Students' action & $79 \%$ \\
\hline 2). & Expressing opinion & $80 \%$ \\
\hline 3). & Responding the question & $61 \%$ \\
\hline
\end{tabular}

It can be seen that mentees had good action in PALP based on how often they are expressing opinion (79\% or 53 mentees were agree), responding the question ( $80 \%$ or 54 mentees were agree), and asking question $(61 \%$ or 41 mentees were agree). It means that the students' motivation toward PALP of second-year students of English education of Ahmad Dahlan University in the academic year 2016/2017 is in high category.

4.3 The Social Factors Affecting Their interest and Motivation

Interest and motivation were affected by social factors. The social factor is a factor which is caused by surrounding, such as environment, social and economic background and family background. To answer this objective, the researcher used questionnaire, observation interview guide. There are 8 statements that represent social factors in the questionnaire. They are number 15, 16, 17, 18, 19, 20, 21 and 22. Social factors are divided into social environment, family background, gender background and socioeconomic background. 


\begin{tabular}{|c|c|c|}
\hline & Aspect & Agree Percentage \\
\hline 3. & \multicolumn{2}{|c|}{ Social factors affecting students' interest and motivation } \\
\hline a. & \multicolumn{2}{|c|}{ Social environment } \\
\hline 1). & Learning environment & $84 \%$ \\
\hline 2). & Friend & $80 \%$ \\
\hline 3$)$. & Mentor & $72 \%$ \\
\hline 4) & Place & $55 \%$ \\
\hline \multirow[t]{2}{*}{ b. } & \multicolumn{2}{|l|}{ Family background } \\
\hline & Distance & $17 \%$ \\
\hline \multirow[t]{2}{*}{ c. } & \multicolumn{2}{|l|}{ Gender background } \\
\hline & Gender & $9 \%$ \\
\hline \multirow[t]{2}{*}{ d. } & \multicolumn{2}{|l|}{ Socioeconomic background } \\
\hline & Job & $18 \%$ \\
\hline
\end{tabular}

It can be seen that the most affected factor was positive learning atmosphere ( $84 \%$ were agree), the second was friend ( $80 \%$ were agree). The third was t mentor (72\% were agree). The last was the place (55\% were agree). Based on the explanation above, it can be concluded that learning atmosphere that include in social environment was the most affected factor that affecting mentees' interest and motivation.

\subsection{The Research Findings and Problems}

Based on the research done by the researcher after doing survey, interview and also observation, the students' interest and motivation is in high category. However, it is not in very high category. There were many cases where the problems still found. There were students who did not attend the meeting, came late to the meeting and also there were students who passive in the learning process. Based on the interview done by the researcher, the problems were caused by some reasons. First, the material used in PALP was not practical. It was more theory more than practical whereas the skill is taught was speaking skill. It should be more practical. Secondly, the mentor was not good enough. There should be the improvement of qualification of the mentors. Therefore the students will have very high interest and motivation toward PALP.

\subsection{An Analysis of Research Findings and the Advantages of Peer Learning}

The research findings showed that the students' interest and motivation toward peer learning is in high category. It is related to the benefit or advantages the peer learning offers. Based on the Boud (1999: 4), there are four advantages of peer learning. They are:

a. Giving the students train in designing and understand in working with each other and also give them an important role in the learning process.

In PALP, the mentor has role to guide the mentee and assist them in learning process. The mentor and mentee should have good relationship in working with each other in order to create good learning result. The researcher tried to find out the relationship between mentor and mentee through observation. The mentee listened towards the mentors well, they did the task when asked by the mentor and they listened to the mentors well. The researcher The researcher also did the interview. The 4 out of 7 said they like their mentors. The remaining 3 mentees said they didn't like their mentors. The reason was their current mentor sometimes couldn't answer their question well. It was so different from their previous mentor who was really good in explaining and answering their question.

b. Allowing the students in expressing their ideas and opinion independently since there is no professional teacher in the group. 
Peer learning allow students to express their ideas or opinion, respond to the question and ask the question. The learning atmosphere is good and comfortable enough in PALP to the students freely do those things. Based on the result finding that the $84 \%$ of the students ( 56 mentees) were agree that they feel the learning was nice. This advantage can be proved on how often the students express their opinion, respond and ask the question. Based on the research finding, $79 \%$ of the students (53 mentees) were agree that they often expressed their opinion in group, $80 \%$ (54 mentees) were agree that they often responded the question in group, and 61\% (41 mentees were agree that they often asked question in group.

c. Increasing the students' skill in communication since the interaction among the students is a vital thing in peer learning in order to realize their strength and weakness in the learning process.

Based on the research findings, $78 \%$ of the students (52 mentees were agree that PALP helped them in increasing their language skill. PALP in this period focused more on increasing students' speaking skill. It can be seen from the comment that mentees' said when asked about the reason why they like studying in PALP. The 4 out of 7 said that PALP increases their skill especially speaking skill. It proved that peer learning can increase students' skill in speaking since students' interaction is important thing in learning process in PALP.

d. Preparing the students to become the part of society who have the responsibility to each other since in peer learning they have an obligation to planning and conducting their own learning and assisting each other.

In conducting the research, the researcher did not observe how the mentor in planning and conducting the learning process. The researcher focuses on students' interest and motivation toward PALP.

4.6 An Analysis of Research Findings and the Relevant Studies' Findings

a. "International Postgraduate Students and Peer Learning" by Evan Hala (2015)

The finding in the present study showed that the students' interest and motivation toward peer learning. The students showed positive attitude toward peer learning. This finding agreed with Evan Hala (2015) study on international postgraduate students' attitudes towards peer learning; their study was based on a sample of 32 students and revealed that students have positive attitudes towards peer learning and that peer learning sessions could help them to understand the academic jargon, contribute to group discussion and learn how to seek help when needed. It is can be seen that peer learning programs have been increasingly implemented in many universities to help students reaching good learning results. People should not underestimate the importance of the peer learning experience which is facilitated by experienced students who successfully completed the same study program. In this study, Evans emphasis on international postgraduate students while the present study focuses on second year students of English education department. Both studies show peer learning create good effects to students.

b. "Assessing the effects of interactive blogging on student attitudes towards peer interaction, learning motivation, and academic achievement" by Yang, C., \& Chang, Y. S. (2012)

The Yang, C., \& Chang, Y. S research finding showed that that interactive blogs, compared with isolated blogs, are associated with positive attitudes towards academic achievement in course subjects and in online peer 
interaction. Students showed positive motivation to learn from peer work, regardless of whether blogs were interactive or solitary. The present research were agree with those result that students showed positive attitude toward peer learning/interaction although the previous study has different type of peer learning. The previous study used interactive blogs. It can be seen that students showed positive motivation to learn from peer work. It has similar result with the present result that student' interest toward Peer Assisted Learning Program is in high category based on impression ( $75 \%$ were agree), confidence (82\% were agree in a group of PALP, $85 \%$ were agree in the class), learning atmosphere (84\% were agree), excitement ( $81 \%$ were agree), new knowledge (73\% were agree) and language skill (78\% were agree). Secondly, the students' motivation toward PALP is in high category based on mentees' individual competency in PALP based on how often they are expressing opinion (79\% were agree), responding the question ( $80 \%$ were agree), and asking question (61\% were agree).

\section{CONCLUSION}

The students' interest and motivation toward PALP is in high category. The social factors affecting their interest and motivation toward PALP are learning environment, friend, mentor and place.

\section{REFERENCES}

Amrai, K., Motlagh, S. E., Zalani, H. A., \& Parhon, H. 2011. The relationship between academic motivation and academic achievement students. Procedia-Social and Behavioral Sciences, 15, 399-402.

Ball, B. 2012. A summary of motivation theories in Journal of Psychology, Vol Maret: 1-26.

Boud, D., Cohen, R., \& Sampson, J. 1999. Peer Learning and Assessment in Assessment \& Evaluation in Higher Education, Vol 24(4): 413-426.

Boud, David, R. Cohen and J. Sampson. 2002. Students Learning from Other Students. London : Koran Page Limited

Evans, H. 2015. International Postgraduate Students and Peer Learning.Journal of Pedagogic Development, 5(3).

Graham, S., \& Weiner, B. 1996. Theories and Principles of Motivation in Handbook of educational psychology, Vol 4: 63-84.

Griffee, D. T. 2012. An Introduction to Second Language Research Methods: Design and Data. Berkeley: TESL-EJ Publications

Harackiewicz, J. M., \& Hulleman, C. S. 2010. The Importance of Interest: The Role of Achievement Goals and Task Values in Promoting the Development of Interest in Social and Personality Psychology Compass, Vol 4(1): 42-52.

Hikmat, F. N. 2012. Student's Interest and Motivation to be a English Teachers of English Education Study Program of Ahmad Dahlan University in The Academic Year of 2011/2012. A Thesis. University of Ahmad Dahlan. Retrieved from http://digilib.uad.ac.id. Accessed on April $3^{\text {rd }} 2017$

Jani, P. Ardiansyah. 2012. Pengaruh Minat dan Motivasi Siswa dalam Kegiatan Esktrakulikuler Seni Musik terhadap Prestasi Belajar Seni Budaya di SMPN 1 Wates. A Thesis. University of Yogyakarta. Indonesia. Retrived from http://eprints.uny.ac.id/9917/. Accessed on April 12 2017. 
Lai, E. 2011. Motivation: A Literature Review Research Report. Retrieved from pearsonassessments.com. Accessed on April 12 2017.

Nicely, T. 2007. The Relationship of College GPA and Job Performance for Teaching Faculty at Blue Ridge Community College in OTS Master's Level Projects \& Papers. Retrieved from http://digital.lib.odu.edu. Accessed on April $11^{\text {th }} 2017$.

Reynolds, W. M., \& Miller, G. E. 2003. Current Perspectives in Educational Psychology in Handbook of psychology, Vol 7: 3- 628.

Ryan, R. M., \& Deci, E. L. 2000. Intrinsic and Extrinsic Motivations: Classic Definitions and New Directions in Contemporary Educational Psychology, Vol 25(1), 54-67.

Schiefele, U. 1991. Interest, Learning, and Motivation in Educational Psychologist, Vol 26(3-4), 299-323.

Seifert, K.2009. Educational Psychology. Switzerland: Saylor Foundation.

Thorndike, E. 1932. The Fundamentals of Learning. New York: Teachers College Press.

Topping, K. J. 2005. Trends in Peer Learning in Educational Psychology, Vol 25: $631-645$.

Yang, C., \& Chang, Y. S. 2012. Assessing the effects of interactive blogging on student attitudes towards peer interaction, learning motivation, and academic achievements. Journal of Computer Assisted Learning, 28(2), 126-135. 